\title{
On climate variability and civil war in Asia
}

\author{
Gerdis Wischnath • Halvard Buhaug
}

Received: 21 February 2013 / Accepted: 6 November 2013 /Published online: 22 January 2014

C The Author(s) 2014. This article is published with open access at Springerlink.com

\begin{abstract}
Effects of climate change are frequently claimed to be responsible for widespread civil violence. Yet, scientists remain divided on this issue, and recent studies suggest that conflict risk increases with higher rainfall, loss of rainfall, higher temperatures or none of the above. Lack of scientific consensus is driven by differences in data, methods, and samples, but may also reflect a fragile and inconsistent correlation for the habitual spatiotemporal domain, Sub-Saharan Africa post-1980. This study presents a comprehensive, multi-scale empirical evaluation of climateconflict connections across Asia, the continent with the highest conflict rate per country. We find little evidence that interannual climate variability and anomalies are linked to historical conflict risk in the simple and general manner proposed by some earlier research. Although a significant parameter coefficient can be obtained under certain specifications, the direction and magnitude of the climate effects are inconsistent and sensitive to research design. Instead, Asian civil wars share central features with violent events elsewhere, proving the main correlates of contemporary armed conflict to be economic and socio-political rather than climatological.
\end{abstract}

\section{Introduction}

The widely held belief that resource scarcities and loss of livelihoods due to climate extremes have the potential to instigate violent conflict (Ban 2007; Obama 2009) has led the United Nations Intergovernmental Panel on Climate Change (IPCC) to consider the threat of armed conflict explicitly in its forthcoming fifth Assessment Report (Adger et al. forthcoming). Thus far, quantitative research has produced mixed results, including reports that conflict risk increases with higher rainfall (e.g., Hendrix and Salehyan 2012; Theisen 2012), loss of rainfall (e.g., Bohlken and Sergenti 2010; Hendrix and Glaser 2007) or higher temperatures (e.g., Burke et al. 2009; O'Loughlin et al. 2012). Another set of studies finds no systematic climate effect (e.g., Buhaug 2010; Koubi et al. 2012), implying an overall lack of scientific consensus on the proposed connection between climate variability and conflict (for recent reviews, see Bernauer, Böhmelt, and Koubi 2012; Deligiannis 2012; Gleditsch 2012; Salehyan 2008;

Electronic supplementary material The online version of this article (doi:10.1007/s10584-013-1004-0) contains supplementary material, which is available to authorized users.

G. Wischnath $\cdot$ H. Buhaug $(\bowtie)$

Peace Research Institute Oslo (PRIO), PO Box 9229, Grønland, 0134 Oslo, Norway

e-mail: halvard@prio.no

G. Wischnath

Freie Universität Berlin, Berlin Graduate School for Transnational Studies (BTS), Berlin, Germany 
Scheffran et al. 2012; Theisen, Gleditsch, and Buhaug 2013; World Bank 2010; see Hsiang, Burke, and Miguel 2013 for a dissenting voice).

Aside from their incompatible findings, there are at least four common features of nearly all contributions to the quantitative climate-and-conflict literature. First, the empirical analyses are limited to Sub-Saharan Africa or regions within the continent. This is understandable, considering that African societies are often considered the most vulnerable to climatic shocks, but it also limits generalizability and ignores the fact that many populations in other parts of the world share key underlying risk factors, such as widespread poverty, discriminatory political structures, dependence on rainfed agriculture, and a history of violence. Second, most earlier research relies on a narrow selection of country-aggregated data with scant consideration of plausible intermediate and contextual effects. In so doing, these studies implicitly assume that a given climatic event has the same destabilizing effect on all societies, at all times. Third, most quantitative studies rely on single operationalizations of climatic conditions and armed conflict, even if the theoretical framework rarely if ever is sufficiently detailed to rule out other dimensions of climate variability or violent conflicts. Lastly, published work usually employs a limited selection of estimation techniques and often fails to evaluate the sensitivity of the main findings to minor changes in model specification and sample inclusion criteria.

This study seeks to remedy these issues by offering a comprehensive investigation of climate-conflict connections across Asia, 1950-2008. Home to nearly half of the world's active civil wars (Themnér and Wallensteen 2012), Asia has the highest density of armed conflicts per country in the world and the continent has contributed little to the recent decline in the global frequency of armed conflict (Goldstein 2011). Our analysis departs from earlier studies along three dimensions; by combining country aggregates with high-resolution gridded data on local environmental and social conditions; by applying a generous set of complementary climate indicators and estimation techniques; and by exploring possible indirect and conditional effects as well as direct relations between climatic conditions and civil war. ${ }^{1}$

Figure 1 illustrates contemporaneous trends in climate and civil war in Asia over the past six decades. A distinct drying is evident across Southeast Asia during the 1990s, and this region is also characterized by larger interannual variability than other parts of Asia. All four regions experienced moderate warming in the sample period. Reflecting the global pattern, the frequency of armed conflict in Asia peaked in the early 1990s, but the decline over the past two decades has been more restrained than elsewhere in the world.

\section{Linking climate anomalies to armed conflict}

Why should local climatic conditions and changes in these affect civil war? Several recent studies that use paleoclimatic data suggest that adverse long-term changes (notably cooling) and subsequent loss of agricultural output historically have been a significant cause of population decline, wars, and civilizational collapse (Tol and Wagner 2010; Zhang et al. 2007; Zhang et al. 2011). The ability of these studies to inform us about likely future impacts of climate change is less clear, however, as industrialization, trade, technological innovation, and other facets of development make social systems less vulnerable to gradual changes in environmental conditions. Instead, virtually all relevant empirical research focuses on effects

\footnotetext{
${ }^{1}$ A civil war is generally understood as a military conflict between an internationally recognized state and one or more non-state organizations resulting in a significant number of casualties (see data section for operational details). We use the terms "conflict" and "war" interchangeably.
} 

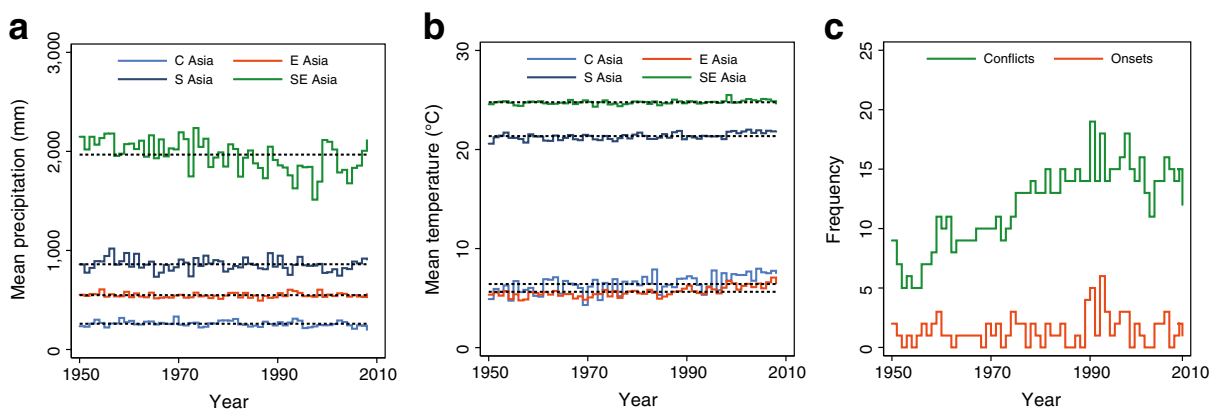

Fig. 1 Trends in climate and conflict across Asia since 1950. Panel (a) shows interannual variation in precipitation across Central, East, South, and Southeast Asia; panel (b) shows interannual variation in temperature; panel (c) shows the contemporaneous frequency of civil war onset and occurrence in Asia

of short-term climate variability, such as interannual changes in temperature and precipitation and yearly deviations from long-term means.

Climate variability is qualitatively different from climate change, yet results pertaining to climate variability are relevant for the climate change debate because global warming is projected to increase the frequency and severity of extreme weather events in many parts of the world. If 100-year droughts become decadal events in the future, anticipated insecurity consequences are also likely to accumulate. Indeed, such anomalies may constitute a greater threat to livelihood security and social stability than gradual changes in means of temperature and rainfall, not the least when we consider possible nonlinearities and tipping points in environmental response to future climate change (Lenton 2011).

Contemporary empirical research on climate variability and conflict is theoretically underspecified but at least four complementary causal explanations can be identified in the literature. The first approach concerns escalating competition over dwindling livelihood resources, such as water, pasture, and cropland. Inability to adapt to such rapid environmental changes plays a central role in the environmental security literature, which argues that in the absence of appropriate response and mitigation systems by the state and/or international actors (e.g., rigorous public goods delivery, resource transfer, insurance schemes, relief aid), violent conflict might erupt (Homer-Dixon 1999). Food insecurity and increasing food prices as a result of climate-induced crop- and pasture failure constitute another central mechanism underpinning this logic (Brinkman and Hendrix 2011). A related argument links increasing scarcities with opportunistic state behavior, where political elites seek to gain politically by playing out social groups against each other or adopting diversionary tactics by blaming the environmental hardship on minority populations (Kahl 2006).

A second argument views forced displacement as an important intermediate link between climatic extremes and conflict (Christian Aid 2007; Reuveny 2007; Smith and Vivekananda 2007). A large influx of people may accentuate extant strains on natural and public goods among the host population and instigate inter-communal tensions. To the extent that the state is perceived as taking side in such disputes (or not ensuring safety for the population), antigovernmental protest and rebellion may be the outcome - the Darfur conflict being a classic example of the proposed climate-displacement-conflict connection (Ban 2007). The conflict potential of environment-induced migration is open to debate, however, and some frame human mobility as a rational coping strategy (Black et al. 2011; Foresight 2011).

Third, climatic extremes, notably abrupt shortages of rainfall, may lead to violent conflict through their negative impact on macro-economic performance (Bohlken and 
Sergenti 2010; Miguel, Satyanath, and Sergenti 2004). This dynamic is primarily relevant for societies dependent on rainfed agriculture for income, food supply, and livelihood security, as found in Sub-Saharan Africa and large parts of Central and South Asia. Loss of state income reduces public goods provision and amplifies economic inequalities, both of which are associated with increased social grievances. At the level of households and individuals, loss of income and unemployment facilitate rebel recruitment (Collier and Hoeffler 2004). Moreover, poor economic growth is strongly linked to political instability and may give rise to armed challenges to the incumbent regime (Alesina et al. 1996).

A fourth proposed argument sees civil conflict risk as a result of increased individual-level aggression in response to rapid environmental change (Hsiang, Meng, and Cane 2011). Citing studies on effects of thermal stress on violent crime, human perception, and violent conduct during baseball games, this explicitly psychological reasoning considers civil war as an aggregate outcome of individual behavior where the state plays no active role in curbing or fueling hostilities. Unlike the other explanations which (often tacitly) assume some extent of time lag in the causal effect, the individual aggression hypothesis prescribes an almost instant reaction to adverse climatic conditions (e.g., Anderson et al. 2000).

For a more comprehensive review of the empirical literature, see Theisen, Gleditsch, and Buhaug (2013). It should be noted that the four theoretical approaches are overlapping in the sense that they predict the same macro-level relationship between climate and conflict, and for that reason it may be challenging to evaluate and compare their accuracy in a large- $\mathrm{N}$ empirical framework. Yet, they differ to the extent that the contexts and conditions under which a climate-conflict link should materialize are different. And while some of these explanations might find some merit in individual cases, we remain agnostic about what might be the most important underlying causal mechanisms driving a climate-conflict link until a consistent and robust correlation has been uncovered.

\section{Materials and methods}

To evaluate the extent to which conflict patterns in Asia overlap with contemporaneous anomalies in climatic conditions, we adopt a comprehensive and unique research strategy that involves two scales of analysis, a generous set of climate indicators, alternative estimation techniques, and various sample definitions. The empirical material builds on a gridded time-series dataset of the Asian continent with a resolution of $0.5 \times 0.5$ decimal degrees and one realization per calendar year for the period 1950 2008 (Tollefsen, Strand, and Buhaug 2012) (Fig. 2). The response variable in our models is a geo-referenced binary indicator of civil war onset, coded by Helge Holtermann as an extension to the PRIO Conflict Site data (Dittrich Hallberg 2012). A civil war is here understood as an armed conflict between a state and one or more non-state group(s) over a clearly stated issue of incompatibility resulting in at least 25 battle-related deaths per year (Themnér and Wallensteen 2012). ${ }^{2}$ Only the cell that hosted the location of initial fighting in each conflict is coded with civil war onset and subsequent years of conflict are dropped from the analysis.

Gridded climate data are drawn from the University of Delaware (NOAA 2011). Four alternative operationalizations of climate variability are explored: (i) absolute

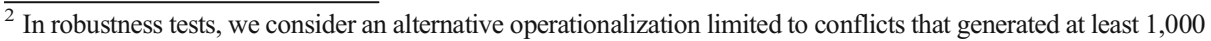
battle-related deaths per calendar year (see Tables 28 and 43 in Supplementary Material).
} 
a

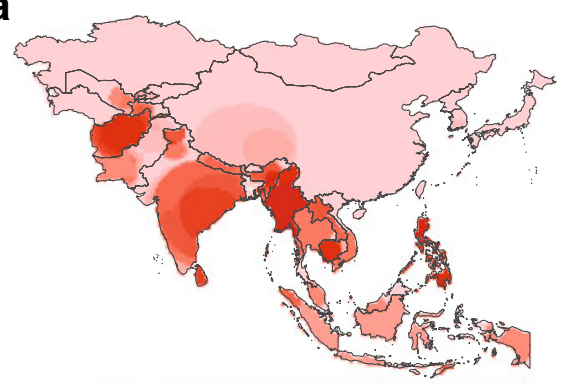

Conflict density Low

C

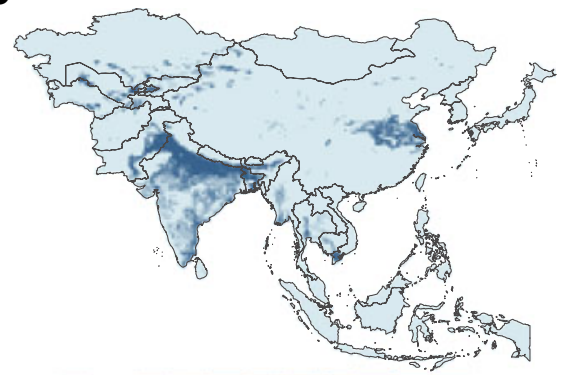

Irrigation $<10 \%$

e

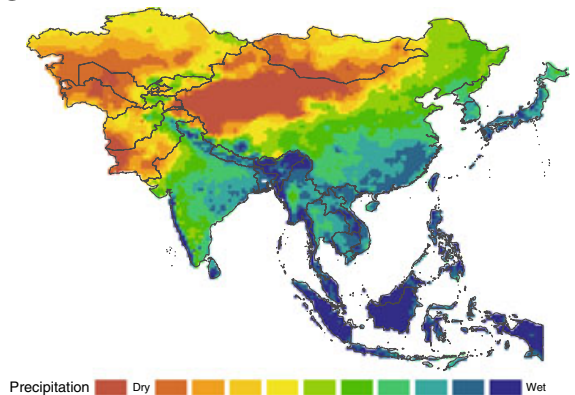

b

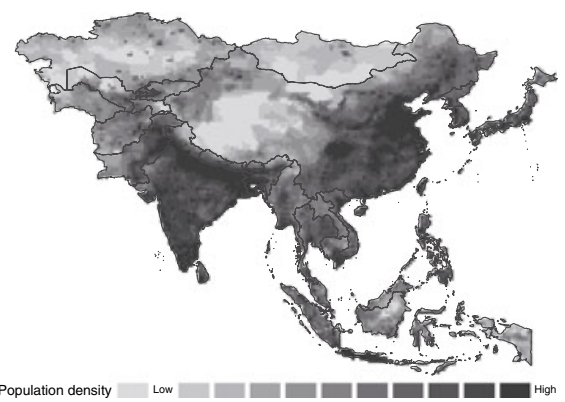

d

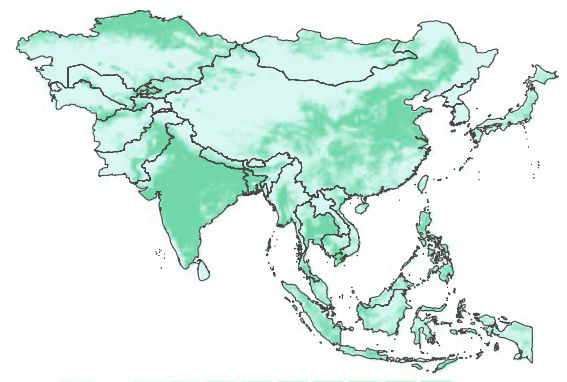

Cropland $<10 \% \quad>90 \%$

f

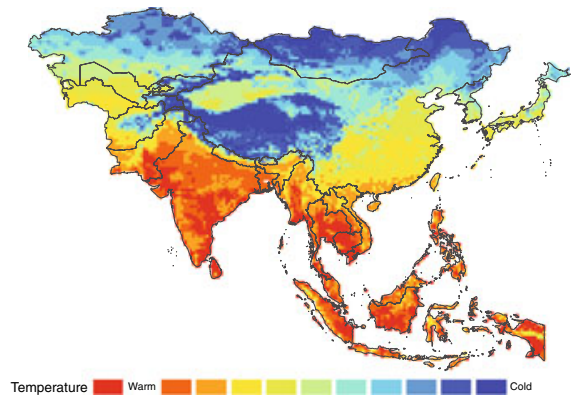

Fig. 2 Spatial distribution of civil conflicts and selected demographic and environmental indicators. Panel (a) shows the density of conflicts by cell, 1950-2008; panel (b) shows population density, 2000; panels (c) and (d) visualize irrigated and rainfed cropland, respectively; panels (e) and (f) illustrate mean cell precipitation and temperature, 1961-90. Variable categories defined as deciles

levels of total annual precipitation $(1,000 \mathrm{~mm})$ and mean temperature $\left({ }^{\circ} \mathrm{C}\right)$; (ii) interannual growth rates in precipitation/temperature (\%); (iii) deviations from the meteorological 1961-90 means ( $\sigma$ ); and (iv) a dichotomous drought indicator based on a standardized precipitation index (SPI6) that captures within-year deficits in precipitation (Guttmann 1999). Unlike the other precipitation variables, a positive value on the SPI6 drought indicator implies a deficit of rainfall. All climate variables are tested with various time lags.

Our baseline civil war model includes the following set of control variables: binary indicators of irrigated and non-irrigated cropland by cell (Bontemps, Defourny, and 
Van Bogaert 2009); cell population (CIESIN 2005); a dummy indicating whether the cell hosts at least one politically marginalized ethnic group (Wucherpfennig et al. 2011); distance to the national capital and nearest neighboring country; plus countrylevel indicators of democracy (Vreeland 2008) and per capita income (Gleditsch 2002; Heston, Summers, and Aten 2011). ${ }^{3}$

The core dataset is built around the grid structure but we estimate country-level models in parallel, where the binary dependent variable is coded 1 in the country year in which a civil war started. The climate indicators capture the yearly country means of local temperature and precipitation (level, growth, deviation) whereas intra-annual drought is captured by a dummy variable flagging whether at least $10 \%$ of the grid cells in a country had a positive value on the local SPI6 indicator in a given year. The country-level models also control for country population size (Heston et al. 2011; World Bank 2011), and both grid- and country-level models include additionally time trends (common or country-specific) as well as corrections for serial correlation by means of a decay function of time since the end of the previous conflict, using a halflife parameter of two years (Raknerud and Hegre 1997).

With the exception of population size, which varies little between time periods, all right-hand side regressors represent last-year conditions in order to allow a time lag in the causal effect on civil war outbreak as well as to reduce problems with reverse causality. Yet, a causal framework that by design excludes within-year connections between weather anomalies and conflict may be incompatible with theoretical arguments that emphasize a sudden and short-term climatic shock effect. For this reason, we document results from models that include current-year measures of climatic conditions in the Supplementary Material.

Civil war risk is estimated through logit, rare-events logit (King and Zeng 2001), fixedeffects logit, and fixed-effects ordinary least squares (OLS) regression. To correct for spatial correlation in the gridded data and reduce computation time, these models were estimated on a subset of the full grid that contains all onset observations and randomly drawn $5 \%$ of the grid cells without conflict incidence. In the core models documented below, we evaluate the direct effect of climate on conflict onset with and without time-varying and location-specific controls. In three sets of additional tests, we consider indirect, interactional, and conditional effects of climate anomalies on civil war risk:

(i) Possible indirect pathways from climate to conflict are explored through two-stage least squares (2SLS) regression, using rainfall and temperature anomalies as instruments for economic growth and food production growth at the county level (Tables 22-27 in Supplementary Material). Due to lack of spatio-temporal migration data, we are unable to test the proposition that climate-induced displacement increases subnational conflict risk (though see Gray and Mueller (2012) and Massey, Axinn, and Ghimire 2010 for country-specific quantitative studies on environmental change and migration).

(ii) Possible interaction effects between climate anomalies and potential local and national 'threat multipliers' are explored through interactions between the climate parameters and

\footnotetext{
${ }^{3}$ Since climate may partly explain some of the control variables, notably economic development and population size, their inclusion may lead to an underestimation of the true impact of nature on conflict. We believe this is less of a concern here since we focus on short-term fluctuations in weather patterns, which are observed across all climate zones. However, latent conflict risk may also differ between countries for unobservable reasons, some of which may correlate with climate (though again perhaps less so with climate variability). Unmeasured heterogeneity can, but need not necessarily, lead to biased estimates, so for this reason we include country fixed effects and time trends in some models.
} 
indicators of political exclusion, extent of agricultural production, and low economic development (Tables 6-20 and 31-40 in Supplementary Material for country- and gridlevel models, respectively).

(iii) Possible conditional effects, where a local climate-conflict effect might only be observed under certain conditions, are explored by estimating the core gridded models on an alternative subsample that only comprises locations with characteristics considered particularly vulnerable to climate extremes, i.e. cells containing a politically marginalized local population and significant agricultural production (Table 41 in Supplementary Material). The findings from these additional tests do not deviate from the core models so only the results from the direct tests are reported here. See Supplementary Material for further details on material and methods and complete documentation of the empirical tests.

\section{Results}

Table 1(a) reports the results for six core models that are estimated in parallel at the country and grid level (model suffix $a$ and $b$, respectively). Focusing on the conventional country-level models first, we evaluate the influence of climatic conditions on civil war risk by means of logistic (Models 1-3a), fixed-effects logistic (Model 4a), and fixed-effects OLS (Models 5$6 a)$ regressions. The three logistic models include standard time-varying controls and introduce alternative measures of climate variability: Interannual growth in precipitation and temperature $(1 a)$; annual precipitation and temperature deviation from the meteorological 1961-90 mean (2a); and the SPI6 indicator that captures within-year drought $(3 a)$. The fixed-effects models (Models 4-6a) include measures of absolute levels of total annual precipitation and mean annual temperature plus time trends.

Comparing the sign of the parameter estimates across specifications, it is clear that neither precipitation nor temperature behaves in a consistent manner. With the exception of intraannual drought (Model 3a), none of the country-level models produces a variable coefficient statistically distinct from zero, and the estimated effects are comparatively weak. For example, Model $1 a$ indicates that one standard deviation above normal levels of rainfall is associated with around $25 \%$ higher conflict risk whereas Model $3 a$ suggests that observations with drought have about $30 \%$ higher conflict risk, all else held constant. To put things in perspective, a similar negative shift in levels of GDP per capita triples the estimated conflict risk (most of this effect is driven by cross-sectional variation). The climate coefficients in the linear fixed-effects models imply smaller and statistically insignificant effects, and similarly specified models without any of the climate variables produce almost identical results for the remaining covariates. This adds to the general picture that temperature and precipitation fluctuations among Asian countries lack a systematic and robust bearing on the spatiotemporal distribution of civil war outbreak.

Table 1(b) synthesizes the estimated impact of the control variables from the logit models. Evidently, correlates of civil war in Asia compare well to those uncovered in global studies (Blattman and Miguel 2010; Hegre and Sambanis 2006): Country-level conflict risk is positively associated with level of democracy, low economic development, involvement in past conflict, and - somewhat less significantly - population size. Extent of irrigated and rainfed cropland and the ethnic configuration of national politics have no systematic effect on conflict risk.

Lack of a strong correlation at the country level might disguise a causal relationship at a local level as both climatic conditions and conflict occurrence may vary substantially within 
Table 1 Correlates of civil war onset in Asia, 1951-2008

\begin{tabular}{|c|c|c|c|c|c|c|c|c|c|c|c|c|}
\hline \multirow{4}{*}{$\begin{array}{l}\text { (a) } \\
\text { VARIABLES }\end{array}$} & \multicolumn{6}{|c|}{ Logit } & \multirow{2}{*}{\multicolumn{2}{|c|}{$\begin{array}{c}\text { FE Logit } \\
\text { (4) }\end{array}$}} & \multicolumn{4}{|c|}{ FE OLS } \\
\hline & \multicolumn{2}{|c|}{ (1) } & \multicolumn{2}{|c|}{ (2) } & \multicolumn{2}{|c|}{ (3) } & & & \multicolumn{2}{|c|}{ (5) } & \multicolumn{2}{|c|}{ (6) } \\
\hline & \multicolumn{2}{|c|}{ Growth } & \multicolumn{2}{|c|}{ Deviation } & \multicolumn{2}{|c|}{ Drought } & \multicolumn{2}{|c|}{ Level } & \multicolumn{2}{|c|}{ Level } & \multicolumn{2}{|c|}{ Level } \\
\hline & a & $\mathrm{b}$ & $\mathrm{a}$ & $\mathrm{b}$ & $\mathrm{a}$ & $\mathrm{b}$ & a & $\mathrm{b}$ & $\mathrm{a}$ & $\mathrm{b}$ & $\mathrm{a}$ & $\mathrm{b}$ \\
\hline \multirow[t]{2}{*}{ Precipitation ( $\mathrm{t}-1)$} & 1.345 & 0.515 & -0.091 & 0.061 & $1.428^{*}$ & 0.338 & -0.334 & 0.225 & -0.016 & $0.001 *$ & -0.007 & $0.001 *$ \\
\hline & 0.783 & 0.382 & 0.087 & 0.090 & 0.563 & 0.239 & 0.697 & 0.149 & 0.032 & 0.001 & 0.032 & 0.001 \\
\hline \multirow[t]{2}{*}{ Temperature $(\mathrm{t}-1)$} & -0.369 & -0.452 & -0.002 & -0.051 & & & -0.222 & -0.032 & -0.010 & -0.001 & 0.011 & -0.001 \\
\hline & 0.811 & 0.554 & 0.126 & 0.156 & & & 0.333 & 0.021 & 0.013 & 0.001 & 0.015 & 0.001 \\
\hline Controls & \multicolumn{2}{|c|}{ Yes } & \multicolumn{2}{|c|}{ Yes } & \multicolumn{2}{|c|}{ Yes } & \multicolumn{2}{|c|}{ No } & \multicolumn{2}{|c|}{ No } & \multicolumn{2}{|c|}{ No } \\
\hline Country fixed effects & \multicolumn{2}{|c|}{ No } & \multicolumn{2}{|c|}{ No } & \multicolumn{2}{|c|}{ No } & \multicolumn{2}{|c|}{ Yes } & \multicolumn{2}{|c|}{ Yes } & \multicolumn{2}{|c|}{ Yes } \\
\hline Common time trend & \multicolumn{2}{|c|}{ Yes } & \multicolumn{2}{|c|}{ Yes } & \multicolumn{2}{|c|}{ Yes } & \multicolumn{2}{|c|}{ Yes } & \multicolumn{2}{|c|}{ Yes } & \multicolumn{2}{|c|}{ No } \\
\hline Country time trend & \multicolumn{2}{|c|}{ No } & & To & & Jo & & Jo & $\mathrm{N}$ & o & & es \\
\hline Observations & 1,251 & 23,356 & 1,251 & 23,356 & 1,251 & 23,356 & 837 & 25,547 & 1,367 & 30,845 & 1,367 & 30,845 \\
\hline Model fit & -247.3 & -399.0 & -248.4 & -400.2 & -245.9 & -399.8 & -200.5 & -491.9 & 0.006 & 0.001 & 0.073 & 0.002 \\
\hline
\end{tabular}

(b)

a b

\begin{tabular}{lcc} 
VARIABLES & Country & Grid \\
\hline Democracy & ++ & ++ \\
GDP capita & -- & - \\
Population & + & ++ \\
Political exclusion & - & ++ \\
Irrigated cropland & - & -- \\
Rainfed cropland & + & -- \\
Distance to capital & & - \\
Distance to border & & -- \\
Conflict history & & ++
\end{tabular}

Panel (a): Regression coefficients with robust standard errors in italics. Model suffix $a$ indicates country-level estimates; model suffix $\boldsymbol{b}$ ( gray column) denotes estimates from grid-level models. Model fit gives log likelihood for logit models and R-squared for OLS models. ${ }^{*} p<0.05$. Panel (b): Symbols denote direction and significance of effect for control variables in the logit models (Models 1-3); + $(-$ ) indicates primary direction of an insignificant effect $(p \geq 0.05),++(--)$ denotes a statistically significant and consistent effect $(p<0.05)$ in the indicated direction. See Tables 3-4 in Supplementary Material for complete regression output from these models

countries. Models $1-6 b$ in Table 1(a) report the results of regression models using grid cells instead of whole countries as units of observation. Again, the climate variables fail to obtain statistically reliable estimates in most models, and again we find the seemingly counterintuitive combination of a positive effect for rainfall growth and a positive effect for within-year drought. Yet, the $p$-values for these estimates are so large that we cannot reject the null of no association. The linear fixed-effects models (5-6b), in contrast, suggest that abundant rainfall is associated with more civil conflict in the following year - diametrically opposing 
mainstream arguments outlined above. However, the effect is small in substantive terms (a one standard deviation increase in rainfall in Model $6 b$ increases the estimated mean absolute conflict risk by around 0.01 percentage points), it adds very little to the models' overall fit, and it fails to be reproduced through maximum likelihood estimation (Model 4b). The estimated temperature effect is never significant but obtains a negative coefficient in nine of the 10 reported models, indicating that warmer-than-average years are more likely to be associated with a decrease in local civil war risk than contributing to new conflicts.

The inconsistent and weak behavior of the climate parameters prevails in models that estimate possible local interaction effects and models limited to areas where climate-induced conflict would be most likely to be observed. Tests of indirect effects via economic performance (GDP) and food production also failed to reveal a robust climate-conflict connection (see Supplementary Material). In contrast, we find a consistent pattern among most of the control variables. Local conflict risk is higher in areas with the following characteristics: Proximity to international boundaries, little or no cropland, high local population density, local ethno-political marginalization, and a recent history of violent conflict (Table 1(b)).

Statistical significance alone often says little about the true impact of a variable, and covariates can have a substantial contribution to a model's overall performance despite a low Z-score (Gleditsch and Ward 2013; Ward, Greenhill, and Bakke 2010). A more meaningful way to assess the effect of climate anomalies on civil war risk is to compare model predictions with and without climate variables. A powerful assessment of a model's forecasting capability is provided by the Receiver Operating Characteristic (ROC). ROC curves visualize the rate of true positives against the rate of false positives across the full range of possible cut-off points $c$ for a binary variable $p^{*}>c$ (Hosmer and Lemeshow 2010). The better a model predicts, the more steeply the curve rises and the larger the area under the curve (AUC, expressed as share of the total area of the plot). The left panel of Fig. 3(a) plots the ROC curves for a baseline country-level model with controls only against Model $2 a$ which contains the most satisfactory climate anomaly indicators, deviation from long-term means.

a

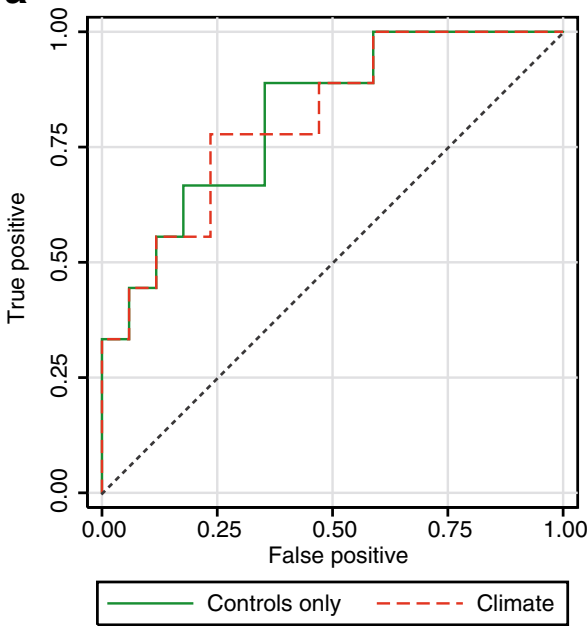

b

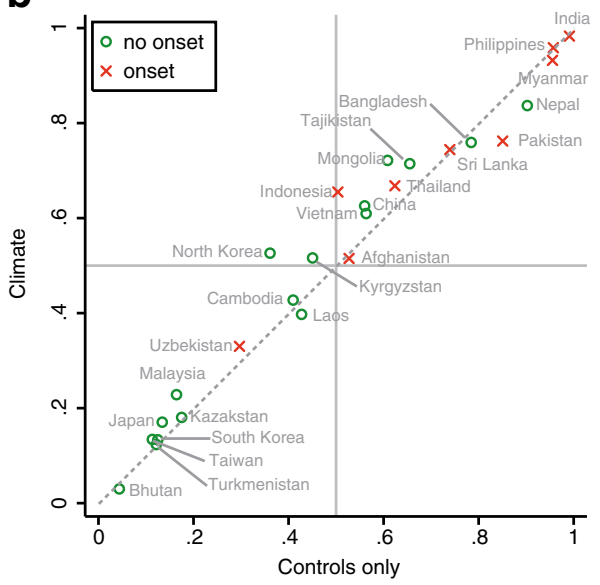

Fig. 3 Out-of-sample prediction of civil war onset by country, 1999-2008. Panel (a) shows the Receiver Operating Characteristic (ROC) curves for the preferred climate model (Model 2a) and a similar model with control variables only. Panel (b) compares 10-year aggregated conflict risk scores from Model $2 a$ with the control model against true observations of civil war onset, 1999-2008, based on the same out-of-sample simulation 
Both models were trained on all observations between 1951 and 1998 and data for the final year of observation were then used to predict civil war onset within the next decade (19992008). In a subsequent step, these decadal predictions are compared with true observations of civil war onset. As indicated by the AUC scores, the climate model actually fares marginally worse in this exercise than the control model (AUC $=0.811$ and 0.817 , respectively), although a chi-square test reveals that this difference is indistinguishable from zero.

Figure 3(b) plots the country-specific prediction scores for the two models against true observations of civil war onset, 1999-2008. The climate model generates higher prediction scores for five of the nine countries that experienced at least one civil war onset out of sample although it also predicts higher conflict risk for 13 of the 18 nonconflict observations, compared to the control model. Notably, the differences in risk scores between the two models are largely trivial, and ordered rankings of Asian countries according to future conflict risk are almost identical (i.e. the plots fall close to the diagonal).

\section{Discussion}

We have found that the estimated effect of climate variability on conflict risk is fragile and sensitive to the scale of analysis, the operationalization of the climate variable, and the choice of estimation technique. Although it is possible to obtain statistically significant parameter estimates under certain model specifications, the median result is a non-finding. Importantly, the evaluation of the subset of cases considered most vulnerable to climatic anomalies failed to reveal a systematic relationship, and models that considered possible indirect effects of climate variability via economic growth and food production also indicated at most a weak and inconsistent impact on civil war outbreak. Lack of geo-referenced migration data prevented evaluating the proposed displacement-conflict link.

A key question remains, however. Can this non-finding be generalized to other continents or is the weak association between climatic anomalies and civil conflict primarily an Asian phenomenon? Although this study alone cannot offer a satisfactory answer, the results reported here are consistent with recent work on Sub-Saharan Africa that explicitly seeks to investigate plausible indirect effects (see Ciccone 2011; Koubi et al. 2012; Theisen, Holtermann, and Buhaug 2011/12). At the same time, our main conclusion differs from some prominent studies that report a significant climate effect (Burke et al. 2009; Hsiang, Meng, and Cane 2011). The reason for this discrepancy, we believe, has less to do with differences in geographical focus or estimation technique but rather is because this study benefits from longer time-series of empirical data, tests a large selection of alternative climate indicators, investigates possible interaction and conditional effects, and exploits recent advances in high-resolution, georeferenced data. Taken together, this empirical strategy bodes for a more rigorous assessment of the proposed climate-conflict relationship.

While climatic events appear to play a trivial role, conflict risk in Asia - as elsewhere - is found to be systematically higher in countries with low levels of economic development, large populations, at least some form of democratic political institutions, and a recent history of armed conflict. Within countries, civil war risk is generally higher in localities with the following characteristics: High population density, proximity to international borders, a politically marginalized local population, little or no agricultural production, and temporal proximity to earlier civil wars (Fig. 4; see also Rustad et al. 2011: 30).

This study should not be considered the last word on the subject matter. Although we have shown that large deviations from normal climatic conditions are not related to historical civil 


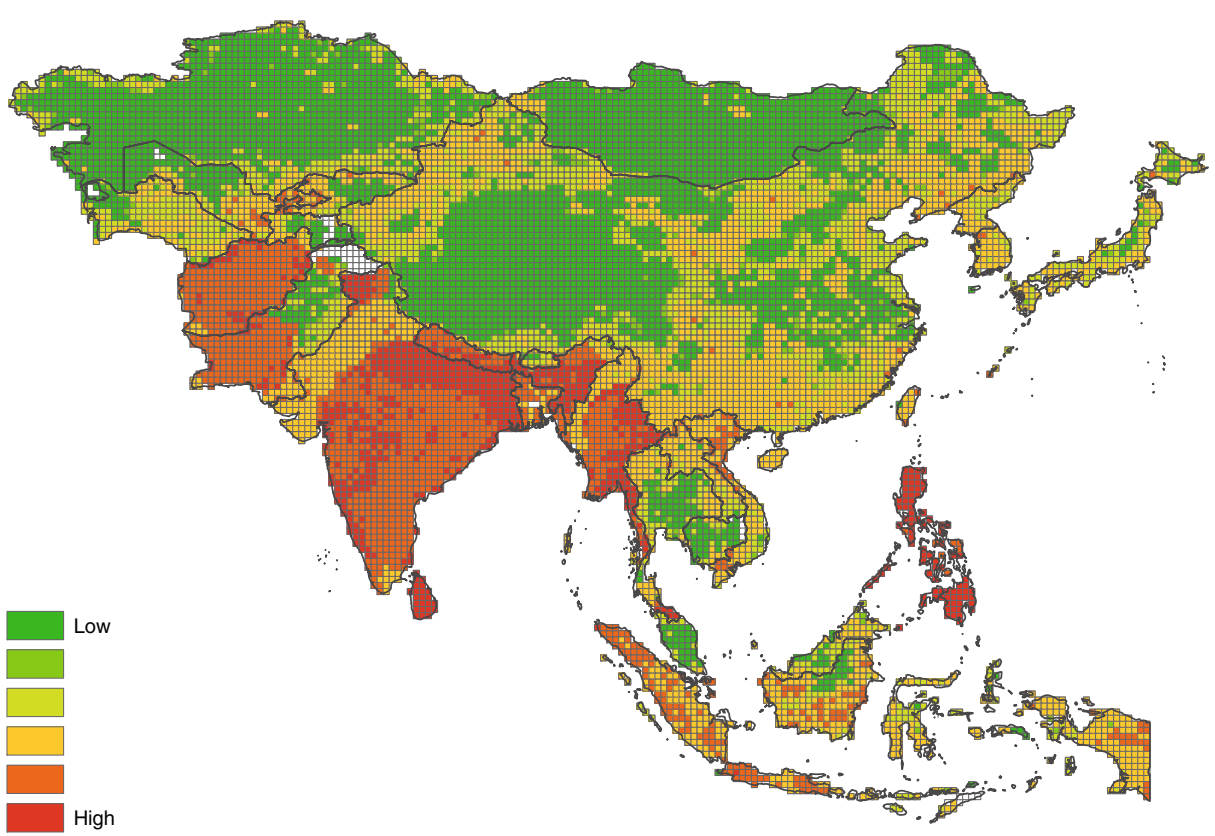

Fig. 4 Spatial distribution of civil war risk across Asia. Risk scores were derived from Model $2 c$ and represent the estimated likelihood of local civil war onset, based on the latest year of available input data

war outbreak in Asia in a consistent and robust manner, this does not imply that climate variability and change are irrelevant for all dimensions of societal security. One important challenge for future research is to investigate how adverse climatic conditions relate to less severe forms of social unrest, including inter-communal violence (Fjelde and von Uexkull 2012) and urban riots (Buhaug and Urdal 2013). At present, data limitations prevent a rigorous empirical analysis of these forms of political violence along the lines of this study. Another issue that should be addressed is implications of climate anomalies and possible intermediate effects on dynamics of political violence. Even if climatic events turn out to have little influence on conflict risk, they may shape the nature of fighting as well as the severity, duration, and geographic spread of hostilities, within countries as well as between them. A third research priority is to invest in disentangling more complex indirect links between climate and violent conflict across multiple temporal and spatial scales. One pertinent question in this regard is the role of forced displacement as a possible catalyst of instability, another relates to how droughts and heat waves among major food producers and resulting spikes in international food commodity prices affect food-importing communities in developing countries.

Acknowledgments We thank colleagues at PRIO and participants at the annual convention of the International Studies Association in San Diego, CA, 1-4 April 2012 and the Jan Tinbergen conference in Berlin, 25-27 June 2012 for useful comments. Replication data are available from PRIO's data pages. This research was carried out with financial support from the Research Council of Norway and the Norwegian Ministry of Foreign Affairs.

Open Access This article is distributed under the terms of the Creative Commons Attribution License which permits any use, distribution, and reproduction in any medium, provided the original author(s) and the source are credited. 


\section{References}

Adger WN et al. (forthcoming) Chapter 12. Human Security. Contribution of Working Group II to the Fifth Assessment Report of the Intergovernmental Panel on Climate Change

Alesina A, Özler S, Roubini N, Swagel P (1996) Political instability and economic growth. J Econ Growth 1: 189-211

Anderson C, Anderson K, Dorr N, DeNeve K, Flanagan M (2000) Temperature and aggression. Adv Exp Soc Psychol 32:63-133

Ban K-m (2007) A climate culprit in Darfur. Washington Post, 16 June

Bernauer T, Böhmelt T, Koubi V (2012) Environmental changes and violent conflict. Environ Res Lett 7:1-8

Black R, Bennett SRG, Thomas SM, Beddington JR (2011) Climate change: Migration as adaptation. Nature 478:477-479

Blattman C, Miguel E (2010) Civil war. J Econ Lit 48:3-57

Bohlken AT, Sergenti EJ (2010) Economic growth and ethnic violence: an empirical investigation of HinduMuslim riots in India. J Peace Res 47:589-600

Bontemps S, Defourny P, Van Bogaert E (2009) Globcover 2009. Products description and validation report. http://due.esrin.esa.int/globcover/. Accessed 1 Feb 2013

Brinkman HJ, Hendrix CS (2011) Food insecurity and violent conflict: Causes, consequences, and addressing the challenges. World Food Programme Occasional Pap 24

Buhaug H (2010) Climate not to blame for African civil wars. Proc Natl Acad Sci U S A 107:16477-16482

Buhaug H, Urdal H (2013) An urbanization bomb? Population growth and social disorder in cities. Glob Environ Change 23:1-10

Burke M, Miguel E, Satyanath S, Dykema J, Lobell D (2009) Warming increases risk of civil war in Africa. Proc Natl Acad Sci U S A 106:20670-20674

Christian Aid (2007) Human Tide: The Real Migration Crisis. Christian Aid.

Ciccone A (2011) Economic shocks and civil conflict: a comment. Am Econ J Appl Econ 3:215-227

CIESIN (2005) Gridded Population of the World Version 3 (GPWv3): Population Grids. http://sedac.ciesin. columbia.edu/gpw/. Accessed 1 Feb 2013

Collier P, Hoeffler A (2004) Greed and grievance in civil war. Oxford Econ Pap 56:563-595

Deligiannis T (2012) The evolution of environment-conflict research: toward a livelihood framework. Glob Environ Polit 12:78-100

Dittrich Hallberg J (2012) PRIO conflict site 1989-2008: a geo-referenced dataset on armed conflict. Conflict Manag Peace 29:219-232

Fjelde H, von Uexkull N (2012) Climate triggers: rainfall anomalies, vulnerability and communal conflict in SubSaharan Africa. Polit Geogr 31:444-453

Foresight (2011) Foresight: Migration and Global Environmental Change Final Project Report. UK Government Office for Science

Gleditsch KS (2002) Expanded trade and GDP data. J Conflict Resolut 46:712-724

Gleditsch NP (2012) Whither the weather? Climate change and conflict. J Peace Res 49:3-10

Gleditsch KS, Ward MD (2013) Forecasting is difficult, especially about the future. J Peace Res 50:17-31

Goldstein JS (2011) Winning the war on war. Dutton, New York

Gray C, Mueller V (2012) Drought and population mobility in rural Ethiopia. World Dev 40:134-145

Guttmann NB (1999) Accepting the standardized precipitation index: a calculation algorithm. J Am Water Resour As 35:311-322

Hegre H, Sambanis N (2006) Sensitivity analysis of empirical results on civil war onset. J Conflict Resolut 50: $508-535$

Hendrix C, Glaser SM (2007) Trends and triggers: climate, climate change and civil conflict in Sub-Saharan Africa. Polit Geogr 26:695-715

Hendrix C, Salehyan I (2012) Climate change, rainfall, and social conflict in Africa. J Peace Res 49:35-50

Heston A, Summers R, Aten B (2011) Penn World Table Version 7.0. http://pwt.econ.upenn.edu/php_site/pwt_ index.php. Accessed 1 Feb 2013

Homer-Dixon TF (1999) Environment, scarcity, and violence. Princeton University Press, Princeton

Hosmer DW, Lemeshow S (2010) Applied Logistic Regression. Wiley, New York

Hsiang SM, Meng KC, Cane MA (2011) Civil conflicts are associated with the global climate. Nature 476:438-441

Hsiang SM, Burke M, Miguel E (2013) Quantifying the influence of climate on human conflict. Science. doi:10. $1126 /$ science. 1235367

Kahl C (2006) States, scarcity and civil strife in the developing world. Princeton University Press, Princeton

King G, Zeng L (2001) Logistic regression in rare events data. Polit Anal 9:137-163 
Koubi V, Bernauer T, Kalbhenn A, Spilker G (2012) Climate variability, economic growth, and civil conflict. J Peace Res 49:113-127

Lenton TM (2011) Early warning of climate tipping points. Nature Clim Change 1:201-209

Massey DS, Axinn WG, Ghimire DJ (2010) Environmental change and out-migration: evidence from Nepal. Popul Environ 32:109-139

Miguel E, Satyanath S, Sergenti E (2004) Economic shocks and civil conflict: an instrumental variables approach. J Polit Econ 112:725-753

NOAA (2011) Delaware climate data provided by the NOAA/OAR/ESRL PSD, Boulder, Colorado, USA. http:// www.esrl.noaa.gov/psd/. Accessed 1 Feb 2013

O'Loughlin J et al (2012) Climate variability and conflict risk in East Africa, 1990-2009. Proc Natl Acad Sci U S A 109:18344-18349

Obama BH (2009) Acceptance Speech for the Nobel Peace Prize. Oslo, 10 December. http://www.nobelprize. org/nobel prizes/peace/laureates/2009/obama-lecture_en.html. Accessed 1 Feb 2013

Raknerud A, Hegre H (1997) The hazard of war: reassessing the evidence for the democratic peace. J Peace Res 34:385-404

Reuveny R (2007) Climate change-induced migration and violent conflict. Polit Geogr 26:656-673

Rustad SCA, Buhaug H, Falch Å, Gates S (2011) All conflict is local: modeling sub-national variation in civil conflict risk. Conflict Manag Peace 28:15-40

Salehyan I (2008) From climate change to conflict? No consensus yet. J Peace Res 45:315-326

Scheffran J, Broszka M, Kominek J, Link PM, Schilling J (2012) Disentangling the climate-conflict nexus: empirical and theoretical assessment of vulnerabilities and pathways. Rev Eur Stud 4:1-13

Smith D, Vivekananda J (2007) A climate of conflict: The links between climate change, peace and war. International Alert

Theisen OM (2012) Climate clashes? Weather variability, land pressure, and organized violence in Kenya, 19892004. J Peace Res 49:81-96

Theisen OM, Holtermann H, Buhaug H (2011/12) Climate wars? Assessing the claim that drought breeds conflict. Int Security 36: 79-106

Theisen OM, Gleditsch NP, Buhaug H (2013) Is climate change a driver of armed conflict? Clim Change 117: 613-625

Themnér L, Wallensteen P (2012) Armed conflict, 1946-2011. J Peace Res 49:565-575

Tol RSJ, Wagner S (2010) Climate change and violent conflict in Europe over the last millennium. Clim Change 99:65-79

Tollefsen AF, Strand H, Buhaug H (2012) PRIO-GRID: a unified spatial data structure. J Peace Res 49:363-374

Vreeland JR (2008) The effect of political regime on civil war: unpacking anocracy. J Conflict Resolut 52:401425

Ward MD, Greenhill B, Bakke K (2010) The perils of policy by p-value: predicting civil conflicts. J Peace Res 47:363-375

World Bank (2011) World Development Indicators 2011. http://data.worldbank.org/data-catalog/worlddevelopment-indicators/wdi-2011. Accessed 1 Feb 2013

World Bank (2010) World Development Report 2010: development and Climate Change. The World Bank, Washington, DC

Wucherpfennig J, Weidmann NB, Giardin L, Cederman L-E, Wimmer A (2011) Politically relevant ethnic groups across space and time: introducing the GeoEPR dataset. Conflict Manag Peace 28:423-437

Zhang DD, Brecke P, Lee HF, He Y-Q, Zhang J (2007) Global climate change, war, and population decline in recent human history. Proc Natl Acad Sci U S A 104:19214-19219

Zhang DD et al (2011) The causality analysis of climate change and large-scale human crisis. Proc Natl Acad Sci U S A 108:17296-17301 